\title{
THE NATURAL MINERAL WATERS OF
}

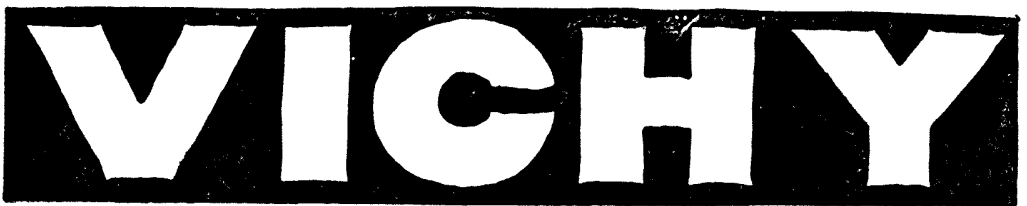

(STATE SPRING S).

CELESTINS,-For Diseases of the Kidneys, Gravel, Gout, Rheumatism, Diabetes, \&c.

GRANDE-GRILLE.-For Diseases of the Liver, Biliary Organs, \&c. HÔPITAL.-For Stomach Complaints.

HaUTERIVE.-An excellent Table Water.

\section{A R
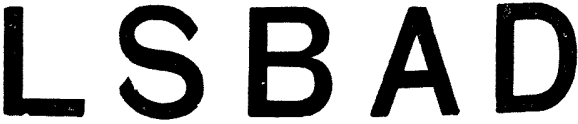 NATURAL MINERAL WATERS}

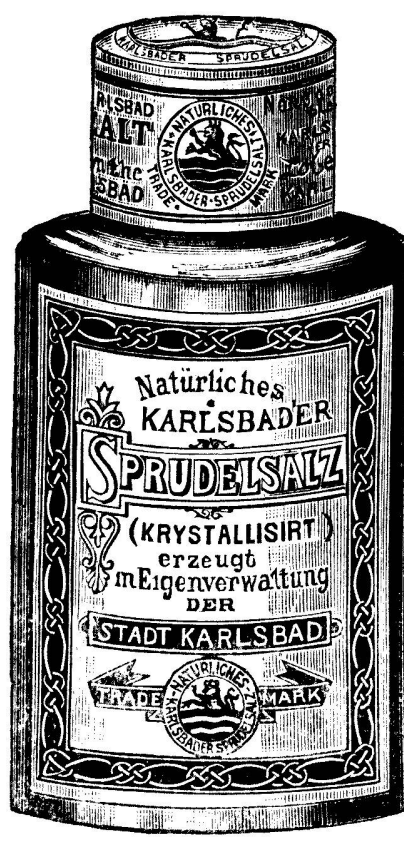

Are imported in Bottles and used in treatment of CIIRONIC GASTRIC CATARRH, HYPER EMIA of the LIVER, GAL 1 STONES, CHRONIC CONSTIPATION, DIABETES, RENAL CALCULI, GOUT, and Diseases of the Spleen, arising from residence in the Tropics or malarious districts.

\section{THE NATURAL CARLSBAD SPRUDEL-SALT}

Is Alkaline, and readily soluble in water. In small and frequen doses it is an efficient dizretic, but as an aperient it should be taken before breakfast, in doses of from $\mathrm{I}$ to 2 teaspoonfuls dissolved in water. To increase the aperient action of the Carlsbad Mineral Water, a teaspoonful of the Natural Salt dissolved in water should be added.

\section{SOLE IMPORTERS-}

INGRAM \& ROYLE, 52, Farringdon Street, London, E.C. 


\section{INDEX TO VOL. VIII., 1894.}

\section{A.}

Accessory cavities of nose-demonstration of, 537 ; disease and treatment of, 130, 370, 597, 677, 742, 757 ; suppuration of, $55,130,370,677,742$; surgery of, $283,427,864$; transillumination of, I 5, 129. Antrum of Ilighmore: acute inflammation of, $370,37 \mathrm{I}$ : cylindroma of, 864 ; dropsy of, 840 ; empyema of, $73,130,370,371,528,540,666$, 742, 798, 81 2, 864, 865, 866; empyema of, and retro-pharyngeal abscess, 866 ; latent empyema of, 397 ; malignant transformation of benign tumours in, 73,862 ; odontoma in, 382,428 ; osteosarcoma of, $75^{6}$; surgery of, 382 , 427, 798. Ethmoid cells : discase ot, 540 ; empyema of, $217,502,668,744$. Frontal sinus: anatomy of, 865 ; empyema of, $197,345,370,496,502$, $743,744,809,866$; operation on, 359 : polypi of, 359,493 ; probing of, 866 ; treatment of, 370 . Sphenord sinus : empyema of, $57,449,497,498,743$; exploration of, 82I ; granulations in, 57, 497; osteo-sarcoma of, 755

Actinomycosis of face, 369

Adenoids, 73, 74, 130, 866; death after removal of, 501 ; and deformity of palate, 458; and enuresis nocturna, 74 ; and mental degeneration, 866 ; and middle-ear disease, and in deaf-mutism, 588 ; operation for, 685 ; tuberculous, 867 ; and torti collis, 458 ; untreated, 766

Air-passages - alumnol in catarrh of, 122; enlarged glands pressing on trachea, 459; foreign bodies in, $\mathrm{I}_{3} 8$, $201,376,459,462$, 501 ; lipoma of, 76; massage of, 257,261 ; obstruction of, 456 ; syphilis of, 132 ; tuberculosis of, 136

Alveolus-fibroma of, $45^{6}$

Aneurism of internal carotid, 205; thoracic, and the recurrent nerves, $45^{8}$

Angina in acute rheumatism, 198 ; in children, 858 ; from copaiba balsam,
368 ; and diphtheria, $68,449,450,452$; follicularis, $234,475,505,595,858$ : with leptothrix, 200; non-diphtheritic, 858; oidica, 69; phlegmonous, I33

Anosmia anil l'arosmia, 197

Antiphones, use of, 873

Antiseptics, 140, 168, 203, 28S, 359, $454,456,593$

Antitoxin - Klebs, 194, 452, 453 ; Behring-Ehrlich, 453, 454, 592, 593, 855 ; Schering - Ahronson, 454, 592, $593,73 \mathrm{~S}$

Aorta-perforation of, 739

Aphonia, $21 \mathrm{I}$; and deafness, hysterical, 776

Argyrosis, I 22

Arytenoid cartilage-gumma of, 224 ; œdema and infiltration of, 222

Arytenoiditis-condition of nerves in, 137,316 ; tubercular, 137,516

Asphyxia, from illuminating gas, 123 Association meetings - Aertzlicher Verein zu Elberfeld, 170; Allgemeiner Aertzlicher Verein zu Köln, I69; American Laryngological Association, 382, 4I7 ; Belgian Society of Otology and Laryngology, 50; British Laryngological and Rhinological Association, I, 87, 341, 489, 802 ; British Medical Association, 557, 607: Congress of American Surgeons and I'hysicians, 540; Deutscher Aertzlicher Verein in St. Petersburg, 170 ; Freie Vereinigung der Cnirurgen Berlins, I69; International Medical Congress in Rome, 231, 310, $3_{3} 8_{3}, 509,58_{3}, 58 s, 68_{5}$ : Laryngological Society of Berlin, $57,5 \mathrm{~S}, 110,447,448$; London Laryngological Sucicty, 43, I43, 151, 209, 219, 439; Medical Society of Berlin, 58 ; Medical Society of Christiania, 779; New lork Academy of Medicine, I66, 293, 298, 359, 749, 754 ; Otologists and Rhinologists of Belgium, 8I7; Pan-American Medical Congress, 759 ; Paris Society of Laryngology, Otology and Rhinology, I 58 ; West London Medico-Chirurgical Society, 847

Astringent tablets, 7.49 
B.

Bony overgrowths and exostoses, 129 Bronchocele, 147

\section{C.}

Canalis facialis, 283

Cerebellar disease and deafness, 85

Cerebral abscess, vide "Intracranial"

Chloroform - in children, 123; death under, I94; in nasal growths, 122, I 23, 373

Choanæ-occlusion of, 127, 373 ; polypus of, 820

Cholesteatoma-273 ; of meatus ex. ternus, 204

Cochlea-necrosis of, 280

Colorado Springs, 461, 762

Coryza-caseosa, 657 ; nervosa, 740

Cretins, skulls of, 436

Crico-arytenoid articulation-anchylosis of, 75 ; in rheumatism, 76 ; syphilis of, 137

Crico-thyroid membrane-perforation of, 535

Croup- $63,64,365,450$; and diphtheria, 62, 193; and croupous diseases, pilocarpin in, $63,390,738$; of nose

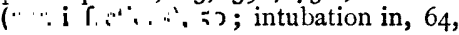
Iر, ij, $, \cdots, \ldots$

Cuneiform sinus-defects of, I70

\section{D.}

Deaf-mutism - 412, 614, 845; and adenoids, 588

Deafness and aphonia-hysterical, 776; phonograph for, 600 ; and paralysis of sterno-mastoid, \&c. , 369 ; total, cured, 330 ; traumatic, 141 ; treatment of, 414

Delavan's address, $4 \mathrm{I} 7$

Diphtheria and angina tonsillaris$68,449,45^{\circ}, 45^{2}, 699$; antidiphtherin (Klebs), I94, 452, 453; antitoxin, 453 $454,592,593,639$ (vide also " $\mathrm{A}$ "), 855; bacteriology, 62, I24, 45o, 699, $736,738,852,853$; Behring-Ehrlich serum, 453, 454, 592, 593; bloodpressure in, 125 ; calomel in, 452, 631 ; and croup, 62, 193; diagnosis of, 194, $364,545,853$; epidemic of, 125 , $452,852,853$; etiology, \&c., 6I, 62, 124, 195, 45 I, 847, 853; heart in, 63; hemiplegia in, 125, 853; immunity, 64 ; intubation in, 137,193 , $365,449,631,867,868$; kidney in, $63,64,591$; laryngo-tracheitis, 853 ; menorial to Local Government Board, 804 ; in New York, 545, 699; paralysis in, 364, 736; and pseudo-diphtheria, 699 ; primary nasal, 591 ; prophylaxis, $450,543,593$; reports of cases, 6r, I 25, 363, 449, 450, 452, 592, 699; in schools, 852 ; and scarlatina, 64 ; sozoiodolic acid, 738 ; tracheotomy in, 193 , 365,451 ; treatment, 62 , I25, 170, 194, $365,452,453,593,631,736,737,847$, 853,854 ; in a wound, 853

Diphtheroid diseases, 62

Dumbness-hysterical, 75, 201

Dyspnœa-case of, 600

\section{E.}

Ear-abscess of fixation, 277; arti ficial disease, I40; auscultation of noises in, 409; caries of, 54, 55, 845, cholesteatoma, 273,845 ; in criminals, $8 \mathrm{I}$; diplacusis, 466 ; disease and cranial complications, 141, 205, 206, 380 ; disease with irritability, 142 ; disease and malaria, 334 ; disease and neurasthenia, 325 ; disease, statistics of, 204 ; in exanthemata, 578 ; epithelioma of, and pyoktanin, 875 ; excision of membrane and ossicles, 205; foreign body in, 54, 206, 873; and labyrinth, sections of, 288 ; labyrinth (vide "L"); larva of fly in, 206; massage of, 376 ; mastoid (vide " $\mathrm{M}$ "); meatus externus, abscess of, 378 ; meatus externus, adhesions in, I4O; meatus externus, cholesteatoma of, 204; meatus externus, exostosis of, 843 ; meatus externus, furuncle of, 378 ; meatus externus, rupture of, 158; middle, operations on, 467 ; middle, physiology of, 405 ; mosquito bite on membrane, 204 ; nose and eye diseases, relations of, 372,467 ; nose and pharynx in school children, 874 ; obstruction of tubæ, 377 ; ossicles (vide "O"); otitis interna traumatica, 377; otitis media (non-suppurative), 562,567 ; otitis media purulenta, 205, 206, 410; otitis media, pain in, 466 ; otitis media in sick infants, 466 ; piercing lobule of, 204, 377; polypus of, 55; reciprocity of the two ears, 85 ; Rinne's test, 608 ; rupture of membrane, 465 ; sclerosis of, 822; suppuration of, 203 , 205, 206, 288, 378, 601, 602, 749, 876 ; suppuration of, after sneezing, 749 ; syphilis of, 275,538 ; temporo-sphenoidal abscess, I4I ; tinnitus, 204; trauma, 52, 141, 165, 377; Weber's test, 29r

Epiglottis-abscess of, 296 ; elonga: tion of, 74, 769; excision of, 461 ; function and anatomy of, zh 2 ; gumma of, 225 ; tumour of, 383 
Epilepsy-with auditory aura, 60I ; and nasal disease, 197,775

Epistaxis, 71, 197, 457, 741, 861 ; ergotin in, 129

Ethmoid bone-disease of, $45^{8}$

Ethmoid cells (vide accessory cavities of nose).

Ethmoiditis, necrosing, 87

Eustachian tube-obstruction of, 377

Exostosis-of septum (vide septum); and bony overgrowths, 129

\section{F.}

Face-actinomycosis of, 369; congenital defects of, I 32 ; paralysis of, 369,601 ; swelling of, 293

Facial nerve-lesions of bony coverings, 142,283 ; post-operative paralysis, 601

Fauces-defects of anterior pillars, 455 ; enlarged pillars, 214 ; and palate, epithelioma of, 219; stenosis of, 154

Formates in ulcers of pharynx and larynx, 764

\section{G.}

Glottis, spasm of, 135

Glycosuria of nasal origin, 822

Goitre, 78, 202, 464, 871, 872 ; accessory lateral, 871 ; congenital, 58 ; electrolysis in, 78 ; exophthalmic, 464; and Graves' disease, 202 ; injection of iodoform, 748, 872; operations for, 748 ; thyroid extract in, 202

Gout-in relation to surgery, I 22; in throat disease, 69,767

Graves' disease, $78,202,203,441,463$, 872 ; following removal of polypi, I 50 Guaiacol-in tuberculosis, 6I; for tonsils, 367

Guaiacum-for tonsils, 368

\section{H.}

Hæmostatic (antiseptic) for nose, 129 Hajek to Grïnwald-letter, 196 Hay fever, i $96,596,759$

Hodgkin's disease, 459

\section{I.}

Incus, extraction of, $60 \mathrm{r}, 823$

Inhalations, 6I

Instruments-acoumeter, 536, 605; for anæsthetics, 599,754 ; antral (maxillary) drainage tube, $607,8 \mathrm{I} 8$; aspirator and injector, 824 ; celluloid face piece and mask, 122; curved curette and curved bistoury for tonsils, 846 ; ear cotton, 600; ear forceps, 845; ear speculum, 376,404, 838; ear screw, 121, 203 ; ear syringe-guard, 376 ; electric apparatus, 778 ; electric curettes, 833 ; electric lamp, 740 ; electric vibrator, 166; endo-laryngeal double curette, I2I ; endo-nasal mirror, 60 ; for extraction of incus, 823; forceps (cutting), I57; furuncle knife, 405, galvanocaustic snare, I46; gas and oxyhydrogen lamp, 846 ; illuminator, I66; laryngeal curette, 846 ; for laryngeal neoplasms, 77; lateral laryngeal forceps, 55 ; laryngeal syringe, 211,446 ; microphonograph, I66; nasal draw knife, 293 ; nasal forceps, 844 ; nasal speculum, 60,194 ; for plugging nose, 838; cesophageal sound, 595; oral dilator, 194; phantom for study of intubation, I2I, 867; phonograph for deafness, 600 ; portable oxyhydrogen lamp, I46; powder insufflator, 226; praxinoscope, 264; rarefacteur, 28I; rolling curette for adenoids, "754; spray apparatus, 846; tongue depressor, I2I ; tonsillotome, I94, 846; tonsil punch, 488 ; transillumination lamp, 846 ; tubes for cleaning nose and naso-pharynx, 293

Intra-cranial-abscess, 205, 269, 466, $501,846,865$; complications of ear disease, I4I, 378, 380; surgery, 6 I

Intubation, $64,65,137,193,239$, $365,449,450,463,631,644,745,779$, $846,867,868$; bibliography of, 651 ; and tracheotomy, 65, 365 (see also "T.")

\section{L.}

Labyrinth-affection of capsule of, 53,286 ; inflammation of, 846 ; and middle ear, sections of, $2 S 8$; syphilis of, 53,288

Laryngitis (see larynx, 1)

Larynx-abnormality, 446 ; abscess of, 296; adenoma of, 504 ; anatoniy, pathology, \&c., 867 ; angioma of, 214 ; benign tumours in, 135 ; carcinoma of, 45 , I 36, I66, 22I, 298, 373, 445, 46I, 746,869 ; chronic disease of, 87,218 , 342,490 ; cyst of, $3{ }^{8} 3,436,746$; in diabetes, 490 ; diaphragm of, I 38 ; disease of, and respiratory murmur, 375 ; electrolysis in, 588 ; epithelioma of, $43,44,147,166,346,383,430,440$, 599,869 ; erysipelas of, I $36,170,387$; extirpation of, $47,48,77,136,166,298$, $383,430,460,461,746$; fistula of, 203 ; foreign bodies in, 76, 91, $382,429,846$; galvano-cautery in, 829; growth in, 
156 ; hæmorrhage in, 136 ; injections into, 310,436 ; innervation of, 135 ; insufflation into, 745 ; laryngitis, 375 $445,459,867$; laryngitis hypertrophica, 535; laryngitis sicca and Stoerk's blenorrhcea, 459 ; laryngo-fissure, 77 9I, 443, 504, 869; and nose literature, 200 ; lupus of, 439,442 ; malignant disease of, $43,44,46,48,443,500$; malignant disease of, radical treatment of, 603 ; models of, 265,867 ; myxoma of, 430 ; necrosis of cartilage, 45 ; neuroses of, 376 ; odema of, 747 ; cdema and hxmatoma, I53; operations in children, 630 ; pachydermia of, 238,383 ; papilloma, 202, 213, 215, $358,383,430,696,749,755,816$; paralysis of, $57,312,345,652,779$; perichondritis of, $45, \mathrm{I} 49, \mathrm{I} 52$; polypus in, I I I ; recurrent growth, 136 ; rhell matism, 76 ; sarcoma, $77,202,383$, 430 ; scleroma of, 201 ; singer's node, $297,383,432$; stenosis of, accidental, I 53 ; stenosis of, acute catarrhal, 146 ; stenosis of, in children, 745 : stenosis of, diphtheritic, $137,193,631,846$; stenosis of, literature of, $65 \mathrm{I}$; stenosis of, non-diphtheritic, 745; stenosis of, syphilitic, 146, 152, 218 , 294, 644, 645, 868 ; stenosis of, tubercular, 375,779 syphilis of, $137,152,218,294,312$ $347,750,869$; syphilo-tuberculosis of, 384 ; in tabes, IIO, 374, 463, 747; trauma of, $17 \mathrm{O}$; tuberculosis of. 75 ,

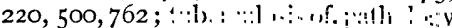
and bacteriology, : $j), 1 j, j 5 \%, j$, 869 ; tuberculosis of, treatment of, at Colorado Springs, 46I, 762 ; tuberculosis of, treatment of, by drugs, I 15 . $447,527,869$; tuberculosis of, treatment of, local, i 85,47 I $, 525,745,762$; tuberculosis of, treatment of, surgical, $173,227,461,509,827$; ulcerations, $75,459,762$; vertigo of, $\mathrm{I} 97$; vocal cords (vide "V")

Lateral sinus - purulent phlebitis, 602 ; suppuration in, 378 ; thrombosis of, $84,141,206,207,266$

Leprosy with throat lesions, I45

Lip-and cheek, swelling of, 293 ; epithelioma of, 373 ; epithelioma of, and carcinoma of larynx, 46I ; reading, 837

Lupus-of nose and larynx, 439 ; of pharynx, 455; of pharynx and larynx, 442; of septum, 502 ; thyroid extract in, 366

\section{M.}

Malleus-extraction of, 56,818 ; ex- traction of, preliminary to antral operation, 623

Massage of mucous membranes, 6I, $257,260,261,740$

Massei's address, 23

Mastoid-inflammation of, 84,321 ; necrosis of, 279; operation on, 335 ; suppuration, operation for, 623 ; transillumination, 465 ; trephining of, 142

Maxilla superior-necrosis of, 360 ; osteoma of, I 32 ; sarcoma of, 456

McBride's address, 557

Mouth-aphthre of, 856 ; bullous affections of, 856 ; carcinoma of, 856 ; gonorrhœal disease of, 593 ; hygiene of, $454,593,856$; mundseuche, 169, 594 ; operations on, 870 ; soor, 594

Multiple sarcoma, 223

Myringography, 327

Myxœdema-79, I 39, 465, 748, 873 ; operative, I39; thyroid gland treatment, 79, I39, 873

Myxo-fibroma of inferior turbinals, 197

Myxo-sarcoma, 196, 756

N.

Nasal feeding, 859

Naso-pharynx-catarrh of, 130,198 ; cyst in, 299; fibroma of, 96, 361, 744; hypertrophy of, 130 ; occlusion of, 457 ; polypus of, 198, 458,846 ; sarcoma of, 360,772 ; syphilis of, 169,457 ; tumour of, operation on, 96, 198, 361, 598 ; tumours of, electrolytic treatment of, 744

Neck-abscess of, 80, 203, 296 ; congenital fistula of, 299 ; enlarged glands, 80 ; epithelioma of glands, 447 ; hydro. cele, 873 ; wound of, 138

Neurasthenia and ear and rhino. pharyngeal disease, 325

Noma, 595

Nose-(accessory cavities, aide " A") anatomy of external nose, 740 ; angioma of, I28; antiseptics in, 456 ; calculus in, $81_{3} 3,863$; carcinoma, 449 , 456; chancre in, 86I; coryza casersa, 657 ; croup of, 50 ; cystic tumour, I96, $300,814,833$; diseases of nose, ear and eye, relations of, 372 ; diseases of nose and eye, 74I ; fibrinous inflamma. tion, 579, 619, 861 ; fibro-sarcoma of, 744 ; toreign bodies in, 70, 501 ; and forehead, hypertrophy of, 94; gumma in, 447, 448; hxemorrhage from, 71 , $197,3^{85}, 457,741,861$; hæmostatics, I29; headaches from, 126; imper. meability, its treatment, $74 \mathrm{I}, \$ 62$; and larynx, lupus of, 439; malignant tumours, 70; malformation of, 126; membranous inflammation of, 197 : 


\section{Index.}

micro-organisms in, $\$ 6 \mathrm{I}$; microscopic anatomy of, 70; models of, I69; movement, pressure, dc., of air in, 859; mucous membrane, hypertrophy of, 70, 654, 74I; mucous membrane, vascular mechanism of, $75 \mathrm{I}$; mucus of, as a germicide, I96; myxoma, 128, 159; myxo-sarcoma of, 772; nasal and post-nasal disease, metal electrodes in, 382,424 ; occlusion of, $75,127,143$, $155,373.457,863$; osclusion of, and glycosuria, 822 ; odontoma in, 382 , 428 ; and palate, lupus of, 817 ; papillary hypertrophy of mucous membrane, 382 , 423 ; plastic operation, 127 ; polypus of, 55,70, I $50,197,344,372,382$, 419, 447, 449; polypus and asthma, 344,372 ; polypus and epilepsy, 197; polypus and ethmoiditis, 382, 419; polypus and Graves' disease, 150; reflexts from, 456,773 ; respiration autograms, 59; sarcoma of, 128, I66, 446,456 ; scleroma of, 597 ; septum of (vide " $S$ ") ; sequestra and tooth in, 299; suppuration of, 128; synostosis in, 807; syphilis of, $127,37 \mathrm{I}, 447$, $86 \mathrm{I}, 862$; and throat (vide " $\mathrm{T}$ "); tooth in, 299, 447; tubercle bacilli in, 860; tuberculosis, 71, 72, 127, 86I ; tumours in, 128, 195, 196; turbinal disease and neuralgia, 810; turbinal disease and headache, 8Io; varix, 654,789

Nostril, contraction of, 224

\section{o.}

Obituary-Billroth, 225 ; S. Guttmann, I7 I

Odol, antiseptic properties of, 454

Esophagus - carcinoma of, 216: diverticulum, 69, 134; foreign body in, 134, 739, 740; pseudo-stricture, 94; rupture of, 456; stricture of, 368,455 , 595,859 ; tuberculous cancroirl ulcer of, 740 ; varix of, $\$ 59$

Olfactometry, 859

Orbit, abscess of, 839

Ossicles-removal of, S2, 205,328 , $601,623,625$; removal of, and caustic treatment, 399

Osteoma of superior maxilla, 53

Otitis (vide ear)

Ozzena, 53, 61. 70, 127, 169, 196, $221,224,372,457,596,597,742,863$

\section{P.}

Palate - cleft, I 32, 169, 44\$, 857 and fauces epithelioma of, 219 ; and fauces, ulcer of, 347 ; soft, alveolar sarcoma of, 595 ; soft, calculus in, 157 ; soft, defects of anterior pillars, 455; soft, enlarged pillars, 214 ; soft, epithelioma of, 67,595 ; soft, and fauces, epithelioma of, 219; soft, innervation, 455; soft, paralysis and anzesthesia, 817 ; soft, pathology of, III; soft, and pharynx, lympho-sarcoma of, 594 ; soft, and uvula (vide " $U$ ")

Paracusis, 415

Paralysis of sterno-mastoid, trapezius and face, $3^{69}$

Parosmia and anosmia, 197

Peritonsillar abscess, 857

Pharyngeal and naso-pharyngeal tumours, retrogression of, 583

Pharyngitis - 595; exudative, 383 , 431 ; follicular, 167

Pharyngocele, 595

Pharyngo-laryngeal tuberculosis, 859

Pharynx-in ataxy, 858; fibrinous infiltration of, 200 ; fistula of, 296 , 815 ; gumma of, 57 ; and larynx, lupus of, $44^{2}$; lympho-sarcoma of, 739 ; malformation of, 805 ; mycosis of, 200 , $383,437,595$; reflexes of, 858 ; in rheumatism, 69; and soft palate, lym. pho-sarcoma of, 594 ; syphilis of, $75^{\circ}$; and tonsil, guaiacum tor, 368 ; and tonsil, mycosis of, 437,746 ; tuberculosis of, 859 ; ulceration of, 222,444 ; and uvula (vide " $U$ "); wound of, 858

Phonograph, 357, 80I

Phosphorus in phthisis, 320

I'ilocarpin ir. croup, 63, 390

Post-nasal space (itide naso. pharynx)

Pre-auricular epithelioma, 846

Pulmonary affections, colouring liquids in, $5^{87}$

Pyriform sinus, hair in, 296

\section{R.}

Reviews of books-Der Kopfschmerz bei Nasen und Rachen-leiden, seine Heilung, dc. (Bresgen), 468; Syphilis in the Innocent (Bulkley), 779; Spätformen hereditarer Syphilis in dem oberen Luftwegen (Gerber), 112 ; Tuberkulose und Lungenschwindsucht, \&c. (Goldschmidt), 467 ; Lehmann's Medicinische Handatlanten, B. IV. (Grünwald), 207 ; Text Book of Diseases of the Ear (Gruber), Ir3; Pharmacopœia of the Hospital for Diseases of the Throat (Harvey), 779; Die Krankheiten der Thymusdruise (Henning), 207 ; Die causale Behandlung der Tuberculose, \&c. (Klebs), 876; Pyogenic Infective 
Diseases of the Brain and Spinal Cord (Macewen), 781 ; Intubation of Larynx in Children (Massei), 207; Manuel pratique des Maladies des Fosses Nasales (Moure), I I4 ; The Discovery of Modern Anresthesia (Nevins), 780; Text Book of Diseases of the Ear and Adjacent Organs (Politzer), 692; Die Krankheiten der Mundhöhle, des Rachens und des Kehlkopfs, \&c. (Rosenberg), 468 ; Klinischer Atlas der Laryngologie und Rhinologie (Schnitzler), 54I; Hygienic Prevention of Consumption (Squire), 381 ; Klinische Geschichte der Pachydermia Iaryngis (Sturmann), 54I ; Improved Siurseon's and Consultant's Visiting List (Viright), I 43; Die Krankheiten der Nase, \&c. (Zarniko) 208; Normale und Pathologische Anatomie der Nasenhöhle und ihrer Pneumatischen Anhänge (Zuckerkandl), I 12

Rhinitis-atrophica, 96, 127, 211 ; fotida, with antral disease, \&c., 22I ; fibrinosa, 597, 619; hypertrophica, 70, 654,741 ; membranosa, 197 ; (7ide also nose)

Rhinoscleroma, 597

Rib fractured by coughing, 462

Rinne's test, 608

Rodent ulcer, 140

Rossi's address, 265, 539

\section{S.}

Saliva, dribbling of, $\mathrm{I} 3 \mathrm{I}$

Salivary-calculus, 66, 13I ; fistula, I3I

Scarlatina-bacteriology, I95; heart

in, 64 ; nephritis in, 64

Schwartze's modification of Stacke's operation, 83

Seaside treatment in nasal, \&c., disease, 860

Septum nasi-angioma of, I28, 770 ; bleeding tumours, 597 ; cutting operations, 382,425 ; deviations of, 242,317 , $457,740,74 \mathrm{I}, 75 \mathrm{I}, 754,862,863$; epithelioma of, 358 ; exostosis, 129 , 863 ; growths on, 148 ; lupus of, 128 , 502 ; malformations of, 863 ; myxangiomatous polypi, 128 ; papilloma, 128 ; perichondritis, 128, 129; polypi of, $70,447,449$; spurs, 2 II ; spurs, electrolysis of, I29, 242 ; tumours of, 128 ; tuberculosis of, 128 ; ulcus perforans, 835,863

Singers' nodes, $297,383,432$

Singing-breathingin, 305 ; methods, 786

Smell, sense of, 456

Sneezing, paroxysmal, 89
Soft palate (vide palate)

Spasm of muscles of jaw, 148

Spheno-maxillary, neurectomy, 838

Stacke's operation, 845

Stapes-movements of, 142 ; removal

of, 82, I4 I, 336, 337

Stomach, foreign bodies in, 462

Struma, congenital, 58

Stuttering and stammering, 67

Sulphuric acid burn of pharynx,

larynx, and asophagus, 824

Swallowing, 362

Swallowing, impediment of, I3I

T.

Taste nerves, histology of, 454

Temporal bone - tracture of, 85 ; from case of otitis, 834

Thiosinamin in tuberculosis, I 5

Throat - bacteria in, 167,195 ; fish-bone in, 362 ; in gout, 69,767 ; leprosy of, 145 ; malignant tumour of, 383,434 ; membranous inflammation of, I33; neurasthenia, 383,436 ; in rheumatism, 69; and nose disease, discrepancies between, I26; and nose disease, etiology of, I ; and nose, microorganisms in, $\mathrm{I}_{3}$; and nose, treatment in the young, 124 ; and nose, antiseptics in, 168

Thyro-arytenoideus, paralysis of, 440

Thyroidectomy, 464

Thyroid gland - abscess of, perforating trachea, 754; accessory, 871 ; carcinoma of, 48; diseases of, 79, 139; enucleation of tumours, 464; exothyropexy, 840 ; and Graves' disease, $202,44 \mathrm{I}, 463,464$; injection treatment, 748 ; in lupus, 366 ; in mental disease, 748 ; in myxœdema, 79, 139 , $465,748,843$; cancroid metastasis, 872 ; methods of secretion, 463 ; in syphilis, $87 \mathrm{I}$; tuberculosis of, 465

Thyro-glossal duct, persistent, 367 , 870

Thyrotomy, 77, 91, 443, 504, 755

Tinnitus-removal of incus for, 601 ; treatment of, 204

Tongue-angioma of, 67 ; defects of, 66; epithelioma of, 132, 594 ; fibroma of, 856 ; inflammation of, 66,169 ; inflammation and necrosis of, 169 ; movements of, 66; removal of, 366 ; sarcoma of, 738 ; tonsil and epiglottis, multiple papilloma of, 857

Tonsil-abscess of, followed by high temperature, 197 ; abscess, peritonsillar, 857 ; angio-fibroma of, 358 ; bristle in, 68 ; calculus in, $55,200,298$; chancre of, 199, 857; disease of, and rheumatism, 
383,437 ; disease of, guaiacol in, 367 ; disease of, guaiacum in, 368 ; hæmorrhage after removal of, 455 ; hypertrophy of, 30I, 368; hypertrophy of, treatment of, 3 or ; hypertrophy of pharyngeal, 68 ; lingual, 68,857 ; mycosis of, 437, 739; oidium albicans in, 69; polypus of, 455; and pyogenic micro-organisms, 739 ; sarcoma of, I33, 199, 383, 434, 446,837 ; tumours of, 739 ; and uvula,

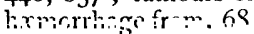

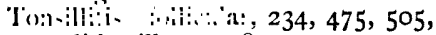
595 ; coli-bacillary, 738

Tonsillotomy, 200; hæmorrhageafter, I32, 455

Trachea-and bronchus, ulcerations of, 138 ; fistula, 870; pressed on by glands, 459 ; retention of secretions, I38; tumours, 870 ; wound of, 138

Tracheotomy, 65, 77, 193, 201, 202, 294, 365, 45I, 460, 462, 749, 868, 869 Transillumination - of antrum of

Iighmore, 15 ; of bones of face, I 5 ; of mastoid, 405 ; of sinuses of nose, I 29

Tubercle bacillus, 375

Tuberculosis at Colorado Springs, $461,762,764$; creosote in, 869 ; creolin in, 447; guaiacol in, 61; menthol in, $46 \mathrm{I}$; phenol - sulphoricinate in, 527 ; phosphorus in, 320 ; spread of, 454 ; thiosinamin in, II 5

Turbinal-carcinoma of, $449,45^{6}$; disease of, and headache, 810; gumma of, 448 ; myxo-fibroma of, 197 ; necrosis of, and neuralgia, 810; varix of, 654 , 789

Turpentine in diphtheria, 125

Tussis nervosa, 447,448

Tympanotomy, 336

Typhoid fever, 66I

\section{U.}

Uvula-cutting of, 200; papilloma of, 216 ; and palate, bristle in, 68 ; and palate, epithelioma of, 56 ; and tonsils, hremorrhage from, 68

\section{V.}

Varix of inferior turbinal, 654,789 Ventricle of Morgagni, anatomy of, 868

Ventricular band - extirpation of, $46 \mathrm{I}$; and arytenoid, swelling of, 218

Ventriloquism, 389

Vertigo-auditory, 874 ; pathology of, 278 ; removal of incus for, 601

Vocal cords - carcinoma of, 821 ; effects of improper singing on, 135 ; fibroma of, 246, 494; fixation of left, 445 ; inverse action of, 135 ; paralysis of, 220, 499 ; singer's node (vide " $\mathrm{S}$ "); and spasm of accessory nerve, 598 ; tubercular ulceration of, 147

Voice-artificial, 460 ; falsetto, 74

\section{W}

Weber's test, 29I

Whistler's address, 803

Whooping cough- 456 ; bromoform in, 64; intubation in, 65; Michael's insufflation in, 454 ; quinine in, 125 ; sublimate in, 855 


\section{NAMES OF AUTHORS.}

\begin{tabular}{|c|c|c|}
\hline Abbot 600 & Bean 739 & Brial 203 \\
\hline Abel 853 & Beausoleil 863,866 & Brickley 455 \\
\hline Abercrombie 87 & Beck 299 & Broeckaert 822 \\
\hline Ahronson $593,73^{8}$ & Beco 818 833 & Bronner I $55,157,210$, \\
\hline $\begin{array}{l}\text { Aiken } 43 \\
\text { Alderson } 851\end{array}$ & $\begin{array}{l}\text { Beebe } 699 \\
\text { Behnle } 787\end{array}$ & $\begin{array}{l}211,212,225,231,276 . \\
310\end{array}$ \\
\hline $\begin{array}{l}\text { Alderson } 85 \mathrm{I} \\
\text { Alexander } 447\end{array}$ & Behring $64,454,592$, & Brook 640 \\
\hline so 759 & 593,855 & Brown, D. $45^{2}$ \\
\hline Allbutt, C. 80 & Bell 205 & Brow11, M. K. 427 \\
\hline $\begin{array}{l}\text { Allen } 132,3^{8} 3 \cdot 436,460 \\
\text { Alsberg } 67\end{array}$ & $\begin{array}{c}\text { Bennett } 155,207,6 \text { I } 8 \text {, } \\
644\end{array}$ & $\begin{array}{l}\text { Brown, P., 74, 594, 760, } \\
765,769,770,775,777\end{array}$ \\
\hline r 198 & Bennett, O. I'. 68,74 , & Browne, 1. 89, 92, 93, 95, \\
\hline at $59 \mathrm{I}$ & 75,127 & $108,132,185,371,490$ \\
\hline lale 379 & Berens $75 \mathrm{I}$ & 5 or, 505,5 \\
\hline 741 & ann $450,85^{6}$ & $\mathrm{SO}_{4}, \mathrm{SO}_{5}, 807,809,8 \mathrm{r} 6$, \\
\hline $67,383,426$ & 265 & 851 \\
\hline Atkinson $85 \mathrm{I}$ & $\mathrm{rd} 63$ & Bruns 138 \\
\hline $\begin{array}{l}\text { Avoledo } 265,276,329, \\
334\end{array}$ & $\begin{array}{l}\text { Bezold } 82 \\
\text { Bidder I } 71\end{array}$ & $\begin{array}{l}\text { Bryan } 132,3^{8} 3,422,42 \% \text {, } \\
540,760\end{array}$ \\
\hline Ayre & $11,140,146$ & $\begin{array}{l}\text { Buchner } 454,855 \\
\text { Buck } 602\end{array}$ \\
\hline aber 49,143 , & 736 & Bulkeley 780 \\
\hline & 225 & I 30,865 \\
\hline 205,467 & $73,77,455$ & ardt 125 \\
\hline ky 63,64 & 196 & 66,601 \\
\hline 123 & 376 & hes 226 \\
\hline 141 & der 639 & 739 \\
\hline $\begin{array}{l}\text { Ball } 136,145,158,224 \text {, } \\
446\end{array}$ & $\begin{array}{l}\text { Blake } 82,335,336 \\
\text { Bleyer } 123,137,166\end{array}$ & $\begin{array}{l}\text { Butlin } 43,48,210,214, \\
220,221,223,366\end{array}$ \\
\hline ng 847 & $38,4,430$ & Buys $8_{33}, 8_{44}$ \\
\hline $73_{8}^{8} 8$ & 54 & \\
\hline $95,813,815$ & 64,449 & 29,130 \\
\hline 378 & $\begin{array}{l}837 \\
867\end{array}$ & 211,219 S11 \\
\hline 375 & $\begin{array}{l}867 \\
446\end{array}$ & $\begin{array}{l}\text { ell } 465 \\
\text { eell } 341\end{array}$ \\
\hline 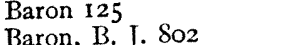 & $\begin{array}{l}446 \\
\text { er } 853\end{array}$ & $855^{3+1}$ \\
\hline $\begin{array}{l}\text { Baron, 13. } 1.002 \\
\text { Barr } 567,583,623\end{array}$ & 464 & 827 \\
\hline Part, Le 861 & $4 I 4,4 I 5$ & pont 864 \\
\hline Bates 130,198 & Bosworth $42 \mathrm{I}, 423,426$, & Is 231,510 \\
\hline ny 737 & & Casselberry $382,383,419$ \\
\hline 65 & 312,317 & 428,436 \\
\hline arten 126 & $\begin{array}{l}\text { y } 152 \\
5011.366\end{array}$ & Castel, Du, 857 \\
\hline $\begin{array}{l}\text { er } 365 \\
52,822\end{array}$ & $\begin{array}{l}366 \\
\operatorname{erg} 69\end{array}$ & 860 \\
\hline energe, 371 & Brasch 452 & Caven 462 \\
\hline eale 43,143 , & Braun 257,264 & Chaillu $73^{6}$ \\
\hline $\begin{array}{l}\text { 1 } 55,209,210,219,220, \\
439,441,444\end{array}$ & $\begin{array}{l}\text { Bresgen } 468,595 \text {, } \\
740\end{array}$ & $\begin{array}{r}\text { Chappell I68, I97, 199, } \\
450,465,749,750,754\end{array}$ \\
\hline
\end{tabular}


Chapuis 86 $\mathrm{I}$

Charrière, De la 860

Charsley 140, 151

Cheval 52

Chiari $71,238,245.2+6$, $264,277,527,685,7+5$, $\$ 56,861$

Clark, II. I60

Cleaver 129

Cleveland 595

Cnopf 460

Cuall 490

Cobb I 28, 770, 776, 772 ,

Cohen, I. Si. I33, I99, $210,219.3^{8} 3$

(when, s.s. 69. 767,768 , 775

Cohn 160

Colbeck I 52

Colladon $265,277,288$, 336

Coillet I $2 \mathrm{~S}$

Colley 857

Collier 93, 94, 95, 90. $107,197,344,352,353$, $354.356,373,490,493$. $490,501,508,802,805$. Sof, So7. 809

Condua 740

Corradi 291, 340, 407, +10

Couetoux I 3 I

Courmont $85 \mathrm{~S}$

Conrtade 140, 158. 372, $37 \mathrm{~S}$

Cox 142

Cozzolino I29, I40, 203 , $272,276,277,321,325$. $340,407,410,415.416$, 537

Crick I 35

Croix, De la 171

Crook 464

Cross $68_{3}$

Curtis I $35,489,495,504$ $507,765,777,778$

1)aac $\delta I$

Dabney 194

D'Aguanno 58 ;

Dahl 466

Dalby 874

Daly $382,421,425,426$, 427

Damieno 383,384

Danet 136

Dansac 130, 137, 316 , 516

Davis 43

Davison 737

Day 463 1)egle 63

Delap 368

Delasalle 870

Delavan 168, 293, 295, $297,298,359,360,363$, $4 \mathrm{I} 7,434,74 \mathrm{I}, 75 \mathrm{I}, 754$, $759,76 \mathrm{I}, 766,767,77 \mathrm{~S}$

Delephine 454

Delic $54,55,840, s_{43}$

Delsaux 53

Delstanche $52,56, \mathrm{~S}_{23}$. $8_{24}, 8_{3} 8$

Dercum $s_{4}$

Dickenson 873

Dickson 78

Didsbury $\$ 63$

Diéulafoy 869

I)ionisio $26 \mathrm{I}, 3^{\mathrm{S} 5}$

Dobic 6I

Dodd 467

Donath 125,853

I) onilles 376

Douglas 359

Downie $574,578,5^{8} 3$

Driter 738

1)rederich 739

I) reschfeld 132

I) rewitt 8.48

I)reyfurs 70, I 28

Drystale 2II, 219

Duncan 64

Duncauson, $\mathrm{I}_{47}$

Dunn 127,196

Dupuis 78

Durham 367

Earenschutz 121

bianter 639

Hiccles 851

Eeman $53,521,822$

Egitli 231,526

Ehrlich 592

lisiselbers $\$ 72$

Eisenmenger 594

Embleton 43

Emerich 135

Engrelhardt $\$ 5^{\circ}$

Engel-Renners 871

Eschbaum 194

Escherich 62, 853

Estien 863

Evans, 87

Ewer 6I

Faber 465

Farlow I 27, 130

Fasano $3^{87}$

Feer $45 \mathrm{I}$

Fellows 37I

Felsenthal 63
Ferreri 399

Ferroud 867

Ficano 276,410

Field 450,562

Fildler 63

Fink 73,862

Finley 459

Fischer 65, 68, 457, 746

Flatau, $57,231,277,389$, 412,414

Foster 152

Fraenkel, 1.134

Fraenkel, B. $58,74,110$, III, $210,219,23 \mathrm{I}, 525$. 527,868

Fraenkel, C. 124

Fraenkel, F. 856

Franke 859

Frankhauser 205

Franks 368

Frazer 365

Fréche 373

French $382,425,433$

Freudenthal jOI, 459

Friedmann I 25

Frosch 62

Galatti $19 j$

(ianderer 282

Garel 128, 526, 528

Garnault $265,337,340$

Garré $7+8,872$

Garzia 3.34

(iatean 354

Gaule 360

Gavino 702

Gellé $142,272,270,283$. $285,328,340,408$

Giendre, Le, 85.

Gerber II 195

(ierhardt 598

Gicrnet 202

Gesche 867

(iibb $45^{6}$

Gibson 588

Gillett 365,867

Glasgow $383,431,432$

Gleitsmann $297,3^{8} 3,427$, $433,434,435,750$

Gluck 77

Gluzenski 527

Goldscheider 68

Goldschmidt 467

Goris 52,838

Gouguenheim 52, 127 , $23 \mathbf{I}, 509,857$

Grabower 57,58 , I I I

Gradenigo $275,276,277$, $278,281,330,340,397$, $407,408,412,413,416$ 
xiv.

Grant 145, 148, 152, 154 , $\mathrm{I} 55, \mathrm{I} 56,265,275,353$, $354,356,404,405,439$, 440, 44 I, 444, 49 I, 494, $496,498,499,506,57$ I $608,618,622,631,656$, $684,798,802,807,809$ $81 \mathbf{1}, 812,813,8$ I6, 8I

Grayson 75, 373, 46I

Grazzi 272, 276, 285, 290, 291, 328

Greenfield 79

Greliche 861

Griffin 370, 457

Griffiths 87

Grönbech $45^{8}$

Grossmann 121

Gruber I 12

Grünwald 70, 207, 457

Guillaume 194

Gulpin 739

Guthrie I23

Guttmann 17 I

Gutzmann 67,389

Guye 820,838

Hacker 455,859

Hagenbach 125

Hajek 196, 458, 54 I

Hall, de Havilland 44, I46, 147, 220, 223, 224

Hamburger 863

Hamilton 61, 67, 134, 455

Hammond 6or, 876

Hardman 372

Harold 748

Harris 43, 206, 376

Harris, T. J. I97

Harsant 619

Harvey 779

Hatan 449

Hayes 802,805

Hecht 70

Hefelmann 856

Heimann $140,447,448$

Hélary I 27

Helfich 377

Hellmann 74I

Helme 738

Hennebert 54

Hennig 207

Henshaw 859

Hensman 143

Herschell $34 \mathbf{I}$

Heryng 121, 173, 227, $231,240,472,587$

Herzberg 858

Herzfeld 57, II 1,448 , 449

Herzog 72

Names of Authors.

Hesse 63

Hey 2 II

Heymann I IO, 597

Hicguet 844

Hildebrandt 170

Hill $1_{52}, 1_{55}, 1_{5} 8,21 \mathrm{I}$, $212,221,574,631,656$, $683,812,876$

Hinkel 422

Hitz 204

Hitzig 87I

Hoag 595

Hofmoki 869

Holden 438

Holloway 123, 373

Holmes 83

Hood 847

Hopkins 76

Hopmann 139, 169, 170 , I96, 527, 597

Hoppe 866

Hornung 740

Hovell 2 IO

Hovorka 740

Huber 69

Hulke I 31

Hulot 854

Hunt 202, 49I

Hurthle 463

Hutchinson 34I, 802

Hutton I4I

Ingals $436,746,759,761$, $764,770,773,776,777$

Isaia 410

Jack I4I

Jackson 6oI

Jacobi 453

Jäger 64

Jagot 200

Jansen 864

Jay 46I

Jeffery 300

Jennings I 24

Jewel II 3

Johnson, Sir C. 210,219

Johnson, W. B. 200

Johnston, McK. 575, 583, $6 \mathrm{I} 9$

Johnston, W. 62

Joins 368

Jones 369

Kaarsberg 744

Kafemann 67

Kanthack 212, 213,215

Karis 23I

Katzenstein 448

Kauffmann $45^{2}$

Kayser 75
Kellcog 370

Kelly 488

Kernung 17 I

Kidd $147,213,214$

King 742

Kirchner 279, 281, 282, 291

Kirmisson 870

Klebs 125, 453,876

Klingel I33, 866

Knapp 300, 575, 625, 683,754

Knauss 869

Knight, C. H. I66, 295, $296,383,417,430,45^{8}$

Knight F. I. 383, 433

Kobler 201

Kobner 169

Köhl I 38

Kohn 852

Koplik $45^{\circ}$

Koser 760

Kossel 592

Kraus 460

Krieg 869

Kronenberg 110

Kronlein I 36

Kruche 737

Kühne 170

Künne 76

Kuttner 6r

Kyle 372,457

Lake $158,376,441,442$, 802

Laker 260,264

Landgraf 58 , I IO, I I I

Lange $66,70,857$

Langenbech 169

Langfeldt $45^{2}$

Langmaid $383,427,433$, 745

Lanz 46I

Lathuraz $45^{8}$

Lauenstein 866

Laurent 53, 82 I

Lautenbach I 2 I, 202

Lauverer 67

Law 96, II 3, 209, 490, $493,802,805$

Lawrence 209, 214

Lawrence, V. E. 365

Lecocq 53,8 : 7

Lederman 455

Lefferts $137,210,219$

Leichtenstein 465

Leidermann 73

Leland 438

Lemke 274

Lerassort 854 
Lermoyez $130,196,73^{8}$, 742,867

Lerwoylz 130

Leuhossek 454

Levy $456,536,605$

Lewis 456

Lichtenstern I39

Lichtwitz 77

Liebert 866

Lilienthal 595

Lincoln 136, 196, 738, 742,867

Lingen 171

Linnell 378

Livon 455

Lodge 95, 107

Loeb 126

L,oewenstein I 70, 866

Logan 760, 768, 772

Love 573,614

Lowe 643

Lowman 23I, 419, 768

Lubliner 242, 527

Lublinsky 129

Luc I28, I 59, 744

Ludewig $265,277,329$

Lund 376

Lunin 170

Luning 136

MacDonald 656, 677

Macewen $78 \mathrm{I}$

MacGiregor 123

Macintyre I, 96, I10, $34 \mathrm{I}, 349,350,353,354$, $357,438,469,489,490$, $494,496,500,802,803$, 805

Mackenzie, H. 375

Mackenzie, J. N. 422, $433,540,761,771,778$

Mackenzie, S. 874

Madeuf 28I, 409, 527

Magnan 858

Mantzel I70

Marchand 864

Marion 857

Marsh 93, 94, I I0, 205, $504,505,802$

Martin 370, 736

Masini 34I, 407

Massei 207, 210, 23I, 24I, 264,526

Masucci 263,527

Matheson 802

Maurel I42

Mayer 167, 300, 302, 754

Mayo 455

McBride 143, 379, 380, 557,657

McCollom 194
McFarlane 600

McPhedran 592

Meierhof 753

Meltzer 873

Mendel 368, 86r

Ménière 141, 165, 377

Mermet 744

Merrick 765, 773, 776, 777

Meschede 203

Mettenheimer 129, 594, 863

Meyer $210,219,7 S_{7}$

Meyer, E. 449

Meyes 818

Michael 24I

Milligan $152,490,502$, $576,607,625,657,68 \mathrm{r}$, $787,805,812,814,815$

Moizard 736, 854

Möller 869

Montaz 739

Moos 265, 266, 272, 276, $278,287,291$

Morelli 66

Moritz 374

Morse 195

Morton 870

Mosler 79

Moullin I98

Moure II 4, 2 I0, 23 I, 242, $245,269,272,526$

Moxham 370

Mulhall 383, 422, 428, 433,436

Munk 62

Muralt 136

Murdoch 619

Nurphy 870

Murray 432, 759,762, 766

Nusehold 596

Mygind 15

Myles 166, 294, 296, 299, $302,359,360,749,75 \mathrm{I}$, $755,756,75^{8}, 85^{8}$

Naegeli I3I

Nesemann 737, 854

Neumann 460

Nevins 780

Newcomb 76, 168, 294, 296

Newton 464

Nichols 69, 293, 296, 302, 753,755

Nikitin 853

Noquet 55, 863

Northrup 63I

Noswinkel 453

Noyes 359,362

Nuvoli 231
O'Dwyer 450, 644

Oertel 852

Onodi 122, 128, 231, 74I

Orr 87

Otto 74

Park 166, 167, 295, 363, $699,753,755$

Parke 438

Parker 157, 158, 168

Partsch 66

Paschkis 454

Pater 456

Paul 202

Pawlowsky 597

Pegler I 52, 575, 802

Perman 738

Permewan 574, 652

Perregauz 872

Phelps 599

Philipp 6I

Phillips, IV. C. 167,749 , 753,755

Piniaczek 77

Plummer 194

Poli 273,538

Polikier 134

Politzer 265, 27I, 274, 286, 288, 329, 34I, 408, 539, 692

Pomeroy 466

Poore, 149

Pope 847

Porcher $135,383,422$, $427,428,436$

Poulsen 80

Preobrascenzki 201

Pryor 747

l'utnam 202

Quinlan 303, 749

Rabot 193

Radcliffe 454

Randall 204, 205

Ranke 65

Raoult 206

Rasch, 466

Raubitschek 855

Rauchfuss 171

Raymond 367

Redman 122

Régis 866

Regli 125

Rehn 463

Reichmann 595

Reid 87

Reinhardt 273, 274, 329, 330

Reinhold 748, 872 
xvi.

Reisz 6I

Rethi 60, 200

Reuter $45^{6}$

Rice $422,424 \cdot 425$

Richardson 196,772

Rickard 125

Ringier 201

Rink 170

Ripault $+57,739, S_{57}$

Ritter 62

Roads 469

Roaldes, I)e, I97, 424, $427,428,429,775,778$

Robertson, WV. F. 622

Robinson 194

Roe $424,426,438,457$, $540,760,773,775$, 776

Rohrer 372

Rolleston 856

Romberg 63

Rose 169

Rosenberg I IO, 447, 468, 697,868

Rosenthal 856

Rosinski 593

Rossi, De 265, 27I, 277 , $281,327,340,341,539$

Roth 70, 7I, 74I, 853

kouge 23I

Roughton 205

Rousseau 829, 833

Roussel 205, $21 \mathrm{I}, 210$, 320. 535

Ruault 23I, 527

Ruedi 137

Rukle 173

Rupl 362

Sainsbury 205

Sajous 231, 438, 527

Sandford 490,501, So5, 865

Sandmann 59

Santi, De I 32, I 52

Sarremone 863

Sartori 265

Sattler 193

Savory, Sir WV. 122

Schaetz 447

Scheff 740

Scheidewaldt 447

Scheier 135, 448, 449

Scheinmann 57, I I I, 126, 448

Scheppegrell I35, 457

Scherck 462

Scheuer 870

Schiffers $50,52,56,834$, 835,837

\section{Names of Authors.}

Schimmelbusch 58

Schleicher 822, 845, 840

Schlesinger 463,747

Schlossarek 121, 867

Schmid, A. 194

Schmidt. II. $23 \mathrm{I}, 263$. 447,527

Schmidthuisen 240,242

Schmicgelow 231, 239, 740,873

Schmitt 595

Schnitzler, A. 464, 501

Scholefield 204

Schotten 139

Schröder 128

Schrötter 122, 210,219

Schubert 453, 593

Schuster 53

Schweiger 193

Scripture 873

Secchi 405,408

Seibert 593

Seiss 204

Selter 138

Semon $43,44,49,147$ $148,149,150,151,152$, I 53, I $58,209,210,2$ I I, $212,2 \mathrm{I} 3,2 \mathrm{I} 4,2 \mathrm{I} 6,2 \mathrm{I} 8$ $219,220,221,222,223$, $225,23 \mathrm{I}, 37 \mathrm{O}, 439,440$, $+41,442,443,444,445$, $631,638,653,656$

Sendziak I I $5,234,603$

Senyey 462

Seward 365

Shaflater 405

sheild 373

thepherd 404

sheplare 82

ihiclds $382,420,428$, 429

Shimwell I 31

Shurley 764

Sichenmann 45 ?

Siebert 125

siegel 169,594

Silk 122

Simonin 450

Simpson, IV. R. $297 \cdot 301$, $360,433,436,750,753$, 758

Sims 127

Smith, R. 305

Smyly, Sir P. 93, 96, 805

Sokolowski231, 525, 527, 555

Solly 461, 762, 764, 766 spencer, IV. (i. 43,143 , I 5 I, 2 I 5

Spicer, F. 480
Sipicer, S. $43,143,152$, $154,155,158,209,210$, $2 \mathrm{II}, 213,2 \mathrm{I} 4,2 \mathrm{I} 5,216$, 2I 9, 222, 439, 441, 442, $445,446,630,656,666$, 812,815

Spilsbury 457

spitzer 741,862

Srquire 381

Ssalitschen 871

Staelin $87 \mathrm{I}$

Stamm 64

Stangenberg 874

Starr I4I

Stern 745

Stewart, 1). 377

Stewart, T. M. 375

Stewart, IV. R. H. 152, $211,216,217,223,224$, 225,445

Stipanics 122

Stockmann 203

Stoerk $210,219,860$

Stoker 93, 96, 341, 350, $352,354,490$

Siolper 600

Strachan 129

Strahlmann 855

Straus 860

Strom 748

Sturmamn 541

Suchannek 70

Sutton 124

Swain $383,430,433,+3{ }^{t}$

Symonds 155, 156, 210 , $218,222,668$

Szenes 277, 288, 291330 , $334.4 \mathrm{I} 2,4 \mathrm{I} 3,4 \mathrm{I} 5$

Sriklai $62,63,390,738$

Tacquet $7+1$

Tait 139

Tansk 458

Tansley, 206

Tarumsorsky 745

Taul, 65

Tautil son

Taylor 85

Theleu 170

Thilsierge 37 I

Thomson, st. C. 231

Thorner $138,204,377$, 469

Tietze 595

Tilnig $17 \mathrm{I}$

Tilley 220, 224

Tissier 742

Topecsin 62

Toti 242

Townsend 592

Trifiletti $231,526,527$ 
Troje 78

Turner 201

Tymowski $5^{88}$

Tyrrell 596

Uchermann 779

Unna 593

Linruh 454

Urbantschitsch $8_{5}$

Urcelay 859

Vanderpoel 168

Variot 853

Vaubin 375

Veillon 858

Vermehren 79

Vickery 84

Villière 854

Virchow 58

Vladar $597,86 \mathrm{I}$

Vulpius 84,85, I94, 453

Wackerle 193

Waggett $87,152,802$

Wagner, C. 199

Wagner, H. L. $38_{3}, 437$

Wagnier 52, 55, 824

\section{Walker 43}

Ward 200

Warden 6 I9

Washbourne I 33

Wassermann 592

Watson $383,434,436$

Weeks 294, 295, 296

Weibgen 737

Weir 462

Weisz 867

Welsch 737

Wernicke 64, 855

Wethered 364

Wetmore 66

Whistler 87, 92, 95, 21 I, $342,349,350,353,354$, $356,490,802,805,807$

White, W. II. 43, I43, 224,364

Widerhofer I2I, 868

Wiehmann 79

Wilkin I 22, 347, 356, 875

Willcocks 225

Williams, C. 368

Williams, W. 43, 143, $219,446,661,787$

Wilson 802
Wingrave $87,96,346$, $351,352,353,35^{8}, 500$, $509,654,657,789,805$, $807,814,815$

Woakes 87 , 105, 350, 35I, 802,805

Woakes, C. 489

Wodon 838

Wolberg $85 \mathrm{~s}$

Wolfenden 438, 469, 475 , $489,490,802,805,849$ Woods 869

Woodward I 36

Wright, G. A. 597,742

Wright, J. I26, 200, 293. $297,300,382,422,423$, $424,432,433,456,492$, $750,751,753,757,75 \mathrm{~S}$ IVroblewsky 68

Wunkler 865

Wurtz I 96

Zappert $45^{2}$

Zarniko 60, 7o, 208, 859

Ziem 740, 862

Zuckerkandl II 2

Zwardemaaker 859 
